\title{
PENGARUH BIAYA, FASILITAS, PELAYANAN DAN MEREK TERHADAP PENERIMAAN MAHASISWA BARU PADA UNIVERSITAS MUHAMMADIYAH TANGERANG TAHUN AKADEMIK 20I2-20I3
}

\author{
Resy Perwithasari \\ Universitas Muhammadiyah Tangerang \\ resy.perwithasari@yahoo.com
}

Keyword
Costs, Facilities, Services, Brands,
Purchasing Decisions

\section{Abstract}

The purpose of this study is to examine and analyze the influence of costs, facilities, services and brands on the acceptance of new students. The sample in this study were 98-20 students of the 20/2-2013 UMT academic year. The analytical tool used is the validity test, reliability test, simple regression and multiple regression. Partial calculation results can be explained that there is a positive and significant influence between costs, facilities, services and brands towards new student admissions, this is indicated by each tcount of each variable $X$ always greater than $t$ table. The results of simultaneous regression testing using the Dolittle Method show that the value of Fcount is greater than the value of Ftable at the standard deviation ( $\alpha$ ) of 0.05 or $5 \%$. So this shows there is a positive and significant influence between costs, facilities, services and brands together towards the acceptance of new students at Muhammadiyah University Tangerang academic year 20/2-20/3. In this study also proves that the simultaneous influence of costs, facilities, services and brands on the acceptance of new students at UMT in the 2012-2013 academic year is strong. The better the price is interpreted, the more complete the facilities, the better the service and the better the brand, the more student acceptance at UMT will be.

C2016 JMB, All right reserved

\section{PENDAHULUAN}

Pendidikan merupakan salah satu dari produk jasa, dengan demikian pendidikan tidak dapat dipisahkan dari sumbernya yaitu lembaga pendidikan. Dalam dasawarsa terakhir ini lembaga pendidikan menunjukan perkembangan dan pertumbuhan yang signifikan baik dari segi kuantitas maupun kualitasnya sehingga mahasiswa sebagai pengguna jasa pendidikan ini dihadapkan kepada banyaknya alternatif pilihan untuk menentukan lembaga pendidikan yang akan dipilih.

Dengan banyaknya lembaga pendidikan tingi yang ada sekarang ini memungkinkan mahasiswa mempunyai beragam alternatif atau pilihan dalam menentukan lembaga pendidikan yang akan dijadikan pilihan, hal ini memicu lembaga pendidikan untuk meningkatkan kualitas dari jasa pendidikan yang ditawarkan kepada masyarakat.

Selain meningkatkan kualitas pendidikan yang ditawarkan kepada mahasiswa, lembaga pendidikan juga menawarkan berbagai macam keunggulan yang diharapkan menjadi daya tarik maupun sebagai referensi calon mahasiswa agar memilih lembaga pendidikan tersebut sebagai tempat untuk mendapatkan pendidikan yang diinginkanya. Kotler (2008:159) menyatakan bahwa "banyak faktor yang dipertimbangkan oleh konsumen untuk memilih serta melakukan keputusan pembelian". demikian pula dalam menentukan perguruan tinggi yang akan dipilih, masyarakat atau calon mahasiswa tentunya 
memperhatikan banyak faktor. Mulai dari biaya, fasilitas, pelayanan serta merek/nama institusi penyedia layanan pendidikan itu sendiri.

Harga menurut Kotler (2008:354) adalah jumlah yang ditagihkan atas suatu produk atau jasa. lebih luas lagi, harga adalah jumlah semua nilai yang diberikan oleh pelanggan untuk mendapat keuntungan dari memiliki atau menggunakan suatu produk atau jasa. Dalam kontek pendidikan harga bisa dikatakan sebagai biaya pendidikan, Kotler (2008:354) juga menyatakan bahwa "harga telah menjadi faktor utama yang mempengaruhi pilihan para pembeli”. Dihubungkan dengan jasa pendidikan, biaya merupakan salah satu faktor yang sangat mempengaruhi keputusan msyarakat dalam menentukan lembaga pendidikan yang akan mereka pilih sebagai tempat mereka menimba ilmu.

Dalam bukunya Kotler (2008:298) menyatakan bahwa "kualitas jasa lebih sulit didefinisikan daripada kualitas produk, Namun kualitas dalam jasa bisa tercermin dari beberapa hal, diantaranya dari kelengkapan fasilitas". Fasilitas merupakan suatu faktor yang sangat penting dan sangat menunjang dalam suatu perusahaan untuk memasarkan produk jasa kepada konsumen pengguna jasa. Fasilitas yang lengkap merupakan suatu daya tarik tersendiri bagi konsumen dalam menentukan pilihannya atau dalam mengambil keputusan terhadap pengguna suatu produk atau jasa.

Institusi jasa yang tidak berkualitas dalam memberikan pelayanan akan ketinggalan dan terlindas dalam persaingan bisnis. $\mathrm{Hal}$ ini menunjukan bahwa pelayanan dalam jasa sangatlah penting. Begitupun dengan lembaga penyelenggara pndidikan tinggi, lembaga perguruan tinggi harus selalu berusaha meningkatkan mutu pelayanan yang berorientasi kepada kepuasan Mahasiswa.

Dari uraian diatas dapat disimpulkan bahwa biaya, fasilitas dan pelayanan merupakan hal yang perlu diperhatikan dalam menarik minat konsumen untuk menjatuhkan pilihan pembeliannya kepada suatu produk jasa. Biaya yang sesuai, fasilitas yang memadai serta kualitas layanan yang baik dalam perusahaan jasa akan memudahkan perusahaan tersebut untuk mendapatkan banyak konsumen dan sebaliknya, perusahaan yang menetapkan biaya yang tinggi, fasilitas yang kurang memadai serta pelayanan yang tidak baik akan kesulitan dalam mendapatkan konsumen.

Universitas Muhammadiyah Tangerang (UMT) adalah salah satu perguruan tinggi swasta yang berkedudukan di kota Tangerang. Untuk memenangkan persaingan UMT terus berupaya memberi harga yang terjangkau untuk peserta didiknya, menyediakan fasilitas pendidikan dan meningkatkan mutu pelayanan, namun upaya tersebut belumlah mencapai titik optimal. Karna pada kenyataannya banyak mahasiswa yang sering menunggak bayaran dan tak sedikit mahasiswa yang drop out karena tidak bisa membayar biaya perkuliahan dan belum ada system pembayaran yang bisa memudahkan mahasiswa untuk membayar biaya perkuliahan. Kemudian fasilitas yang diberikan masih kurang contohnya wifi yang disediakan belum sesuai harapan mahasiswa, parkiran yang disedikan belum bisa menampung seluruh kendaraan yang ada. Dan dari segi pelayanan, belum adanya pelayanan online yang bisa memudahkan mahasiswa untuk melihat nilai, mengisi KRS, serta pelayanan administrasi yang diberikan kurang ramah, sigap dan sebagainya. Akan tetapi belum optimalnya fasilitas dan pelayanan tidak membuat UMT kekurangan mahasiswa, diusianya yang baru 3 (tiga) tahun UMT sudah memiliki mahasiswa dengan jumlah 13.054 Mahasiswa (BAAK UMT). hal ini bisa terjadi karena berbagai faktor termasuk diantaranya biaya perkuliahan dan merek/nama UMT itu sendiri.

\section{Pengembangan Hipotesis}

Berdasarkan kajian terhadap studi teoritis dan empiris yang menunjukan hubungan antar variabel biaya, fasilitas, pelayanan dan merek dan penerimaan mahasisa baru pada universitas muhammadiyah tangerang maka untuk memperjelas hubungan antar variabel tersebut dibuatlah kerangka konseptual yang terletak pada Gambar I dibawah ini. 


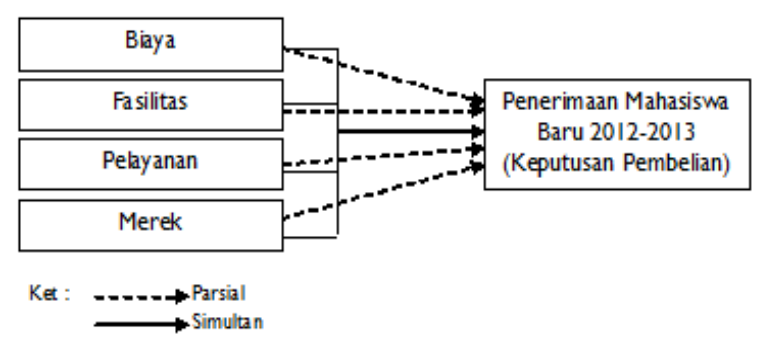

\section{Gambar I. Kerangka Berpikir}

Berdasarkan telaah teori dan kerangka konseptual tersebut diatas maka dirumuskan hipotesis dalam penelitian ini adalah: (I) biaya berpengaruh terhadap penerimaan mahasisa baru; (2) fasilitas berpengaruh terhadap penerimaan mahasisa baru; (3) pelayanan berpengaruh terhadap penerimaan mahasisa baru; (4) merek berpengaruh terhadap penerimaan mahasisa baru; dan (5) biaya, fasilitas, pelayanan dan merek secara bersamasama berpengaruh terhadap minat pesrta didik.

\section{METODE PENELITIAN}

Populasi dalam penelitian ini adalah seluruh mahasiswa baru Universitas Muhammadiyah Tangerang angkatan tahun 20I2-20I3 yang berjumlah 477I (BAAK UMT), Adapun tekhnik pengambilan sampel yang peneliti gunakan adalah probability sampling. Menurut J. Supranto (2003:70), menyatakan bahwa probability sampling adalah "suatu sampling yang pemilihan objek atau elemen dari populasi yang akan dimasukkan di dalam sample di dasarkan atas nilai probality".

Untuk menentukan ukuran atau jumlah sampel dari populasi, peneliti menggunakan rumus pengukuran sample menurut pendapat Slovin. Dalam perhitungan ini peneliti menetapkan batas kesalahan maksimal 10\%. dari hasil perhitungan, maka yang menjadi sampel dalam penelitian ini adalah sebanyak 98 responden. Untuk menentukan sampel yang menjadi responden dari setiap fakultas maka dilakukan perhitungan dengan pendekatan sebagai berikut :

Responden fakultas

$=\frac{\text { jumlah mahasiswa fakultas TA } 2012-2013}{\text { jumlah seluruh mahasiswa TA } 2012-2013} \times 98$

Berikut jumlah data responden sesuai menurut fakultas masing-masing :

Tabel I. Data Responden Sesuai Dengan Fakultas

\begin{tabular}{|c|l|l|ll|}
\hline No & \multicolumn{1}{|c|}{ Fakultas } & Populasi & \multicolumn{2}{|c|}{$\begin{array}{c}\text { Sampel } \\
\text { (pembulatan) }\end{array}$} \\
\hline 1 & Ekonomi & 1365 & 28,03 & $(28)$ \\
\hline 2 & Agama Islam & 300 & 6,17 & $(6)$ \\
\hline 3 & Kesehatan & 392 & 8,05 & $(8)$ \\
\hline 4 & FKIP & 1079 & 22,17 & $(22)$ \\
\hline 5 & Hukum & 169 & 3,47 & $(4)$ \\
\hline 6 & Teknik & 1043 & 21,42 & $(21)$ \\
\hline 7 & $\begin{array}{l}\text { Ilmu Sosial } \\
\text { dan Ilmu } \\
\text { Politik }\end{array}$ & 389 & $8.00 \quad(8)$ \\
\hline 8 & $\begin{array}{l}\text { Program } \\
\text { Pasca Sarjana }\end{array}$ & 34 & 0,69 & $(1)$ \\
\hline & JUMLAH & 4771 & \multicolumn{2}{|c|}{98} \\
\hline
\end{tabular}

Data dikumpulkan dengan cara menyebar kuisioner kepada responden berdasarkan kepada indikator setiap variabel yang digunakan. Data diolah menggunakan metode regresi linier sederhana dan regresi linier berganda.

\section{HASIL PENELITIAN DAN PEMBAHASAN}

\section{Uji Validitas}

Berikut disajikan hasil uji validitas, pendekatan yang digunakan adalah dengan melakukan korelasi antar skor butir pertanyaan dengan total skor variabel. Jika $r$ hitung $>r$ tabel dan nilai positif, maka pertanyaan atau indikator dinyatakan valid (Ghozali, $2006: 45$ ).

Tabel 2. Hasil Uji Validitas

\begin{tabular}{|c|c|c|c|c|}
\hline Variabel & Kuisioner & $\mathrm{r}_{\text {hitung }}$ & $\mathrm{r}_{\text {tabel }}$ & Kriteria \\
\hline & Butir I & 0,6776 & 0,1975 & Valid \\
Biaya & Butir 2 & 0,7498 & 0,1975 & Valid \\
$\left(X_{1}\right)$ & Butir 3 & 0,7730 & 0,1975 & Valid \\
& Butir 4 & 0,8643 & 0,1975 & Valid \\
\hline \multirow{4}{*}{ Fasilitas $\left(X_{2}\right)$} & Butir I & 0,8704 & 0,1975 & Valid \\
& Butir 2 & 0,9227 & 0,1975 & Valid \\
& Butir 3 & 0,9228 & 0,1975 & Valid \\
& Butir 4 & 0,8774 & 0,1975 & Valid \\
\hline
\end{tabular}




\begin{tabular}{|c|c|c|c|c|}
\hline Pelayanan $\left(\mathrm{X}_{3}\right)$ & $\begin{array}{l}\text { Butir I } \\
\text { Butir } 2 \\
\text { Butir } 3 \\
\text { Butir } 4\end{array}$ & $\begin{array}{l}0,8350 \\
0,8531 \\
0,8244 \\
0,6391\end{array}$ & $\begin{array}{l}0,1975 \\
0,1975 \\
0,1975 \\
0,1975\end{array}$ & $\begin{array}{l}\text { Valid } \\
\text { Valid } \\
\text { Valid } \\
\text { Valid }\end{array}$ \\
\hline $\begin{array}{c}\text { Merek } \\
\left(\mathrm{X}_{4}\right)\end{array}$ & $\begin{array}{l}\text { Butir I } \\
\text { Butir } 2 \\
\text { Butir } 3 \\
\text { Butir 4 }\end{array}$ & $\begin{array}{l}0,6675 \\
0,8030 \\
0,7989 \\
0,8203\end{array}$ & $\begin{array}{l}0,1975 \\
0,1975 \\
0,1975 \\
0,1975\end{array}$ & $\begin{array}{l}\text { Valid } \\
\text { Valid } \\
\text { Valid } \\
\text { Valid }\end{array}$ \\
\hline $\begin{array}{c}\text { Penerimaan } \\
\text { Mahasiswa Baru } \\
\text { (Y) }\end{array}$ & $\begin{array}{l}\text { Butir I } \\
\text { Butir 2 } \\
\text { Butir 3 } \\
\text { Butir 4 } \\
\text { Butir 5 } \\
\text { Butir 6 } \\
\text { Butir 7 } \\
\text { Butir } 8 \\
\text { Butir 9 } \\
\text { Butir 10 } \\
\text { Butir II } \\
\text { Butir } 12 \\
\text { Butir I3 } \\
\text { Butir } 14 \\
\text { Butir } 15 \\
\text { Butir } 16 \\
\text { Butir } 17 \\
\text { Butir } 18 \\
\text { Butir } 19 \\
\text { Butir } 20\end{array}$ & $\begin{array}{l}0,7337 \\
0,5533 \\
0,6445 \\
0,6863 \\
0,5123 \\
0,6112 \\
0,7583 \\
0,5749 \\
0,5545 \\
0,5560 \\
0,6172 \\
0,4543 \\
0,6622 \\
0,7331 \\
0,2561 \\
0,6600 \\
0,2112 \\
0,5435 \\
0,6401 \\
0,5620\end{array}$ & $\begin{array}{l}0,1975 \\
0,1975 \\
0,1975 \\
0,1975 \\
0,1975 \\
0,1975 \\
0,1975 \\
0,1975 \\
0,1975 \\
0,1975 \\
0,1975 \\
0,1975 \\
0,1975 \\
0,1975 \\
0,1975 \\
0,1975 \\
0,1975 \\
0,1975 \\
0,1975 \\
0,1975\end{array}$ & $\begin{array}{l}\text { Valid } \\
\text { Valid } \\
\text { Valid } \\
\text { Valid } \\
\text { Valid } \\
\text { Valid } \\
\text { Valid } \\
\text { Valid } \\
\text { Valid } \\
\text { Valid } \\
\text { Valid } \\
\text { Valid } \\
\text { Valid } \\
\text { Valid } \\
\text { Valid } \\
\text { Valid } \\
\text { Valid } \\
\text { Valid } \\
\text { Valid } \\
\text { Valid }\end{array}$ \\
\hline
\end{tabular}

Dari tabel 3 diatas terlihat hasil uji reliabilitas menunjukkan bahwa nilai Cronbach alpha dari masing-masing variabel lebih besar dari nilai penguji, dapat disimpulkan bahwa semua variabel reliabel untuk dilakukan pengujian selanjutnya.

\section{Hipotesis Parsial}

Berikut disajikan hasil perhitungan parsial dengan menggunakan regresi sederhana :

Tabel 4. Hasil Uji Regresi Parsial

\begin{tabular}{|l|l|l|l|l|l|}
\hline $\begin{array}{c}\text { Variabe } \\
\mathrm{I}\end{array}$ & \multicolumn{1}{|c|}{ Persamaan } & Korelasi & $\begin{array}{c}\text { Koefisien } \\
\text { Determinasi }\end{array}$ & \multicolumn{1}{c|}{$\mathrm{t}$ hitung } & $\begin{array}{c}\mathrm{t} \text { tabel } \\
(\mathrm{\alpha}=0,05)\end{array}$ \\
\hline $\mathrm{XI}$ & $\mathrm{Y}=56,10106+1,565203 \mathrm{X}$ & $0,5 \mathrm{I}$ & $26 \%$ & 5,779348 & $\mathrm{I}, 66159$ \\
\hline $\mathrm{X} 2$ & $\mathrm{Y}=69,80444 \mathrm{I}+0,698534 \mathrm{X}$ & 0,32 & $10,2 \%$ & 3,2920635 & $\mathrm{I}, 66123$ \\
\hline $\mathrm{X} 3$ & $\mathrm{Y}=51,35603+2,069874 \mathrm{X}$ & 0,65 & $42,2 \%$ & 8,3370904 & $\mathrm{I} .6622$ \\
\hline $\mathrm{X} 4$ & $\mathrm{Y}=52,0195 \mathrm{I}+\mathrm{I}, 690165 \mathrm{X}$ & 0,39 & $15,2 \%$ & 4,128164 & $\mathrm{I} .6614$ \\
\hline
\end{tabular}

Dari tabel 4.3 dapat diketahui bahwa semua variabel independen ya'ni variabel $X I$ (biaya), $\mathrm{X} 2$ (fasilitas), $\mathrm{X} 3$ (pelayanan) dan $\mathrm{X} 4$ (merek) memiliki hubungan secara parsial dengan variabel dependen atau variabel $Y$ (penerimaan mahasiswa baru di Universitas Muhammadiyah Tangerang) dengan besaran hubungan masing masing variabel adalah $0,5 \mathrm{I}$, $0,32,0,65$, dan 0,39 . Artinya biaya memiliki hubungan yang sedang, fasilitas memiliki hubungan yang lemah, pelayanan memiliki hubungan yang kuat dan merk memiliki hubungan yang lemah dengan penerimaan mahasiswa baru.
Dari tabel 4.3 dapat diketahui juga bahwa hasil perhitungan regresi secara parsial menyatakan keempat variabel independen ya'ni variabel XI (biaya), X2 (fasilitas), X3 (pelayanan) dan $X 4$ (merek) masing-masing berpengaruh sebesar $26 \%, 10,2 \%, 42,2 \%$, dan $15,2 \%$ terhadap variabel $Y$ (penerimaan mahasiswa baru di Unversitas Muhammadiyah Tangerang) tahun akademik 2012-2013. Artinya semua variabel bepengaruh positif dan signifikan terhadap penerimaan mahasiswa baru di UMT. Dimulai dari variabel biaya, hasil penelitian ini menyatakan bahwa biaya berpengaruh positif dan signifikan terhadap penerimaan mahasiswa baru di UMT, artinya semakin baik biaya dalam 
artian semakin baik rekayasa untuk meringankan dan memudahkan pemabayaran maka akan semakin meningkat pula penerimaan mahasiswa baru UMT. Kebijakan yang berkaitan dengan harga tidak bisa berdiri sendiri karena juga dipengaruhi oleh tingkat harga yang ada di pesaing, kualitas produk yang dijual dan juga daya beli pelanggan atau masyarakat.

Penelitian ini sejalan dengan yang dikemukakan Hurriyati (2005:152) bahwa biaya mempunyai peranan penting dalam dalam proses pengambilan keputusan pembeli. Harga dapat membantu para pembeli untuk memutuskan cara memperoleh manfaat atau utilitas tertinggi yang diharapkan berdasarkan kekuatan daya belinya. Dengan demikian adanya harga dapat membantu para pembeli untuk memutuskan cara pengalokasian kekuatan membelinya pada berbagai jenis barang dan jasa. Pembeli membandingkan harga dari berbagai alternatif yang tersedia kemudian memutuskan alokasi dana yang dikehendaki.

Yang kedua adalah variabel fasilitas, fasilitas berpengaruh positif dan signifikan terhadap penerimaan mahasiswa baru di UMT, artinya semakin baik fasilitas maka akan semakin meningkat pula penerimaan mahasiswa baru UMT. Hanya saja kontribusi fasilitas terhadap penerimaan mahasiswa baru lebih kecil dari kontribusi variabel lain yang ada dalam penelitian ini, kontribusi kecil ini terkonfirmasi benar, terbukti walaupun UMT belum memiliki fasilitas yang cukup baik tetapi penerimaan mahasiswa baru tahun 2012-20I3 mencapai 477I mahasiswa.

Yang ketiga adalah variabel pelayanan, pelayanan berpengaruh positif dan signifikan terhadap penerimaan mahasiswa baru di UMT. Aartinya semakin baik pelayanan maka akan semakin meningkat pula penerimaan mahasiswa baru UMT, Temuan yang menyebutkan bahwa kualitas layanan dapat mempengaruhi ketertarikan konsumen secara langsung diantaranya bisa diaplikasikan dalam aktivitasaktivitas kecil sebagai perwujudan indikator emphaty, seperti membantu calon mahasiswa menuliskan formulir, atau sekedar menyediakan minum bagi calon mahasiswa potensial yang masih mencari informasi, walaupun terlihat kecil namun hal tersebut mempunyai arti yang begitu besar bagi calon mahasiswa. Hal ini sejalan dengan teori yang disampaikan oleh Kotler dan Keller (2008: 139), yang menyatakan bahwa pada dasarnya sikap pelanggan yang loyal maupun tidak loyal merupakan akumulasi masalahmasalah kecil yang ada dalam perusahaan, sehingga perusahaan harus berusaha untuk memberikan pengalaman yang menarik bagi pelanggan.

Yang keempat adalah variabel merek, merek berpengaruh positif dan signifikan terhadap penerimaan mahasiswa baru di UMT. Artinya semakin baik citra merek maka akan semakin meningkat pula penerimaan mahasiswa baru UMT, nama persyarikatan Muhaammadiyah yang menaungi UMT tidak bisa dilepaskan dari UMT keduanya saling mengikat dan membentuk citra yang positif dimata masyarakat. Hal ini sejalan dengan apa yang disampaikan Park, Jaworski, and Maclnnis, (1986) bahwa perusahaan yang mempunyai produk dengan citra merek yang kuat akan mendapatkan posisi yang lebih baik, dapat menopang keunggulan bersaing dan meningkatkan pangsa pasarnya.

Dari tabel 4.3 menyatakan bahwa semua hipotesis yang menyatakan ada pengaruh secara parsial dari biaya, fasilitas, pelayanan dan merek terhadap penerimaan mahasiswa baru di UMT dterima, dan semua pariabel berpengaruh positif dan signifikan.

Dari keempat variabel bebas yang diteliti maka bisa dilihat bahwa pelayanan memberikan kontribusi pengaruh yang paling postif dan signifikan terhadap penerimaan mahasiswa baru di UMT, disusul variabel biaya, merek dan fasilitas. Bisa dikatakan bahwa pelayanan memberikan sumbangsih yang paling besar dibandingkan tiga variabel lainya terhadap penerimaan mahasiswa baru di Universitas Muhammadiyah Tangerang. artinya mahasiswa UMT tahun akademik 20I2-2013 lebih memperhatikan kualitas pelayanan dalam menjatuhkan pilihanya. sedangkan fasilitas adalah variabel yang sangat rendah pengaruhnya terhadap penerimaan mahasiswa baru, ini berarti mahasiswa yang mendaftar kuliah di 
UMT tahun akademik 20I2-20I3 tidak terlalu menjadikan fasilitas yang ada di UMT sebagai alasan mereka memilih UMT sebagai tempat menimba ilmu, terbukti walaupun masih kurangnya fasilitas seperti gedung dan ruang kelas yang belum memadai, tempat parkir yang tidak luas tidak menjadikan halangan terhadap lonjakan penerimaan mahasiswa baru khususnya tahun akademik 2012-2013 yang tercatat sebanyak 477I mahasiswa.

\section{Hipotesis Parsial}

Berikut disajikan hasil perhitungan simultan dengan menggunakan regresi berganda:

Tabel 5. Hasil Uji Regresi Berganda

\begin{tabular}{|c|c|c|c|c|c|}
\hline Vari & Persamaan & Korelasi & $\begin{array}{c}\text { Koefisien } \\
\text { Determinasi }\end{array}$ & f hitung & $\begin{array}{c}f \text { tabel } \\
(\alpha=0,05)\end{array}$ \\
\hline 资 & $\begin{array}{l}Y=28,7925472+1,0997601 X_{1}- \\
0,136334968 X_{2}+1,53544266 X_{3}+ \\
0,95043 X_{4}\end{array}$ & 0,51 & $60,52 \%$ & 35,25959 & 2,47 \\
\hline
\end{tabular}

Dari tabel 5 dapat diketahui bahwa semua variabel independen ya'ni variabel $X I$ (biaya), X2 (fasilitas), X3 (pelayanan) dan $\mathrm{X} 4$ (merek) secara bersama-sama memiliki hubungan dengan variabel dependen atau variabel $Y$ (penerimaan mahasiswa baru di Universitas Muhammadiyah Tangerang) dengan besaran hubungan 0,5I. Artinya biaya, fasilitas, pelayanan dan merek secara bersama-sama memiliki hubungan yang yang sedang dengan penerimaan mahasiswa baru.

Dalam tabel 5 dapat dilihat juga besarnya $\mathrm{KD}=60,5 \%$ yang berarti bahwa secara simultan dari biaya, fasilitas, pelayanan dan merek berpengaruh positif dan signifikan terhadap penerimaan mahasiswa baru tahun akademik 2012-20I3 dengan besaran 60,5\% dan sisanya $39,5 \%$ dipengaruhi oleh faktor lain yang tidak diteliti dalam penelitian ini.

\section{PENUTUP}

\section{Kesimpulan}

Dari penelitian melalui pembahasan dari, maka penulis dapat menarik kesimpulan sebagai berikut :

I. Biaya mempunyai pengaruh terhadap penerimaan mahasiswa baru di Universitas Muhammadiyah Tangerang, hal ini dibuktikan dengan nilai thitung lebih besar dari nilai ttabel yaitu nilai thitung $>$ ttabel $=$ $5,779348>1,66159$. Dan besaran kontribusi efektif biaya terhadap penerimaan mahasiswa baru sebesar 26\%, hal ini ditunjukan dengan diketahuinya nilai KD sebesar $26 \%$.

2. Fasilitas mempunyai pengaruh terhadap penerimaan mahasiswa baru di Universitas Muhammadiyah Tangerang, hal ini dibuktikan dengan nilai thitung lebih besar dari nilai ttabel yaitu thitung $>$ ttabel $=$ $3,2920625>1,66123$. Dan besaran kontribusi efektif fasilitas terhadap penerimaan mahasiswa baru sebesar 10,2\%, hal ini ditunjukan dengan diketahuinya nilai KD sebesar 10,2\%.

3. Pelayanan mempunyai pengaruh terhadap penerimaan mahasiswa baru di Universitas Muhammadiyah Tangerang, hal ini dibuktikan dengan nilai thitung lebih besar dari nilai ttabel yaitu thitung $>$ ttabel $=$ 8,3370904> I,6622. Dan besaran kontribusi efektif pelayanan terhadap penerimaan mahasiswa baru sebesar $42,6 \%$, hal ini ditunjukan dengan diketahuinya nilai KD sebesar $42,6 \%$

4. Merek mempunyai pengaruh terhadap penerimaan mahasiswa baru di Universitas Muhammadiyah Tangerang, hal ini dibuktikan dengan nilai thitung lebih besar dari nilai ttabel yaitu thitung $>$ ttabel $=$ $4,128|64>1,66| 4$. Dan besaran kontribusi efektif merek terhadap penerimaan mahasiswa baru sebesar 15,2\%, hal ini 
ditunjukan dengan diketahuinya nilai KD sebesar 15,2\%.

5. Secara simultan antara biaya, fasilitas, pelayanan dan merek berpengaruh positif terhadap penerimaan mahasiswa baru di Universitas Muhammadiyah Tangerang tahun 2012, hal ini dibuktikan dengan nilai Fhitung kebih besar daei nilai Ftabel yaitu Fhitung $=35,25959>$ Ftabel $=2$ 2,47. Dan besaran kontribusi efektif antara biaya, fasilitas, pelayanan dan merek secara bersama-sama terhadap penerimaan mahasiswa baru sebesar 60,52\%, hal ini ditunjukan dengan diketahuinya nilai KD sebesar $60,52 \%$.

\section{Saran}

I. Untuk Universitas Muhammadiyah Tangerang

Dari hasil penelitian ini didapatkan bahwa pelayanan berpengaruh positif terhadap penerimaan mahasiswa baru di UMT paling tinggi dibandingkan variabel independen yang lain dan fasilitas berpengaruh positif terhadap penerimaan mahasiswa baru paling rendah dibandingkan variabel independen yang lain dalam penelitian ini, dengan demikian UMT harus semakin meningkatkan mutu pelayanan kepada mahasiswa agar tetap bisa menjadi kampus pilihan bagi para calon mahasiswa berikutnya.

Namun dalam hal fasilitas walaupun pengaruhnya sangat rendah terhadap penerimaan mahasiswa baru sebaiknya tidak menjadikan pihak UMT untuk tidak memperhatikan fasilitas, karena banyaknya mahasiswa baru yang memilih UMT sebagai tempat menimba ilmu pastinya mereka datang dengan harapan bahwa akan mendapat pelayanan dan fasilitas yang memadai. Apabila fasilitas di UMT tidak ditingkatkan, dikawatirkan mahasiswa akan kecewa sehingga mengeluarkan keluhanya dikalangan masyarakat. $\mathrm{Hal}$ ini pastinya akan berpengaruh buruk terhadap citra UMT dimata masyarakat.

Oleh karena itu sebaiknya UMT meningkatkan fasilitas yang ada dengan menambah sarana prasarana yang lebih lengkap lagi mengingat yang tersedia sekarang masih belum optimal.

2. Untuk penenlitian berikutnya:

a. Penelitian mendatang perlu menguji dan menambah variabel-variabel baru seperti kinerja pemasaran atau variabel lain yang dipandang mempunyai pengaruh penting terhadap penerimaan mahasiswa baru.

b. Dalam penelitian ini tidak difokuskan kepada masing-masing fakultas, maka untuk penelitan mendatang perlu adanya penelitian yang fokus kepada penerimaan mahasiswa baru disetiap fakultas.

\section{DAFTAR PUSTAKA}

Ahuja, Pramila \& G.C. Ahuja. (2004). Membaca: Secara Efektif dan Efisien. Kiblat Buku Utama. Bandung.

Assegaff, Mohammad. 2009. Pengaruh Kualitas Pelayanan Terhadap Kepuasan Pelanggan. Jurnal EKOBIS, Vol. I0, N0. 2

Arep dan Tanjung. 2003. Manajemen Motivasi. Grasindo, Jakarta.

Alma, Buchari. 2007. Manajemen Pemasaran dan Pemasaran Jasa. Alfabeta. Bandung

Arikunto, Suharsimi. 2010. Manajemen Penelitian. Rineka Cipta. Jakarta

Athoillah, Anton. 2010. Dasar-dasar Manajemen. Pustaka Setia. Bandung.

Badawi, Achmad (dkk). 2013. Buku Panduan Penyusunan Proposal dan Skripsi. Fakultas Ekonomi Universitas Muhammadiyah Tangerang. Tangerang.

Boyd, Harper W, Orville C. Walker, Jean Claude Larreche. 2000. Manajemen Pemasaran Suatu Pendekatan Strategis dengan Orientasi Global. Erlangga. Jakarta.

Ferrinadewi, Erna. 2008. Merek dan Psikologi Konsumen. Graha Ilmu. Jakarta

Handoko, T. Hani. 2003. Manajemen. BPFE Yogyakarta. Yogyakarta

Karina, Pradityas. 20II. Analisis Pengaruh Brand Image, Biaya Pendidikan, dan Fasilitas Pendidikan terhadap Keputusan Mahasiswa Melanjutkan Studi Pada Program Diploma iii Fakultas Ekonomi Universitas Diponegoro Semarang. Skripsi. Semarang : Program Sarjana Universitas Diponogoro 
Kashmir dan Jakfar. 2007. Studi Kelayakan

Bisnis. Prenada Media Group. Jakarta.

Kholmi, Masiyah dan Yuningsih, 2004. Akuntansi Biaya, Cetakan Keempat, UMM Press, Malang.

Kotler dan Armstrong. 2000. Dasar-dasar Pemasaran. (Sindoro). Prenhallindo, Jakarta.Erna

Kotler, Philip and Keller, Kevin, Lane. 2007. Marketing Management, (Bob Sabran). Erlangga. Jakarta.

Kotler, Philip dan Amstrong, Gary. 2008, Prinsip-prinsip Pemasaran, Edisi 12 Jilid I, (Bob Sabran). Erlangga. Jakarta.

Kotler, Philip and Keller, Kevin, Lane. 2009. Marketing Management. Edisi 12 jilid I, (Benyamin Molan). Indeks. Jakarta.

Laksana, Fajar. 2008. Manajemen Pemasaran, edisi pertama. Graha Ilmu. Yogyakarta.

Lupiyoadi, Hamdani. 2006. Manajemen Pemasaran Jasa, Edisi Kedua. Salemba Empat. Jakarta.

M. Ikbal Hasan. (2002). Pokok-Pokok Materi Statistik 2 (Statistik Inferensif). Edisi kedua. Jakarta: PT Bumi Aksara.

Mulyadi, 200I, Akuntansi Manajemen : Konsep, Manfaat dan Rekayasa. Salemba Empat. Jakarta.

Oxford Advanced Learner's Dixtionary of current Six Edition. 2004. Oxford University press. England

Parasuraman, A. Valarie A. Zeithaml and Arvind Malhotra (2005). E-S-QUAL:A MultipleItem Scale for Assessing Electronic Service Quality. Journal of Service Research.

Payne, Adrian. 2007. Service Marketing Pemasaran Jasa. Andi. Yogyakarta

Rangkuti, Freddy. 2004. The Power of Brand. Gramedia Pustaka Utama. Jakarta.

Ricky, Griffin. 2003. Manajemen. Erlangga. Jakarta.

Riduwan. 2010. Dasar - dasar Statistika. Alfabeth. Bandung.

Saladin, Djaslim. 2007. Intisari Pemasaran \& Unsur - unsur Pemasaran. Linda Karya. Bandung.

Schiffman, Kanuk. 2008. Consumer Behaviour,sevent Edition. cetakan keempat. Indeks. Jakarta

Simamora, Henry. 2002. Akuntansi Manajemen. UPP AMP YKPN. Jakarta

Subagyo, Ahmad. 2010. Marketing in Business. Mitra Wacana Media. Jakarta.
Sugiyono. 2012. Metode Penelitian Kuantitatif, Kualitatif, dan $\mathbf{R} \& \mathbf{D}$. Alfabeta. Bandung.

Surachman. 2008. Dasar-dasar Manajemen Merek, Edisi pertama, Cetakan pertama. Malang: Bayumedia Publishing

Sunyoto, Danang. 20II. Metodologi Penelitian. CAPS. Yogyakarta.

Sunyoto, Danang. 2012. Dasar - dasar Manajemen Pemasaran. CAPS. Yogyakarta.

Susetyo, Budi. 20I0. Statistika Untuk Analisis Data Penelitian. PT. Refika Aditama. Bandung.

Sutedjo, Wira. 2007. Panduan layanan konsumen. Grasindo. Jakarta

Susanto, AB dan Himawan Wijanarko. 2004. Power Branding Membangun Merek Unggul dan Organisasi Pendukungnya. Mizan Publika. Jakarta

Swastha, Basu. 20I0. Manajemen penjualan. Edisi 3. BPFE. Yogyakarta.

Terry, R George. 2003. Dasar-dasar manajemen. Bina Aksara. Jakarta

Tjiptono, Fandy. 2005. Pemasaran Jasa. Edisi Pertama. Bayumedia Publishing. Malang

Tjiptono, Fandy. 2008. Strategi Pemasaran. Andi Offset. Yogyakarta.

Umar, Husein. 2000. Riset Pemsaran dan Perilaku konsumen. PT. Gramedia pustaka Utama. Jakarta.

Usmara, A. 2003. strategi baru manajemen pemasaran. Amara books. jakarta

Ridwan, Iskandar. 2013. Pengaruh Pelayanan terhadap Keputusan Pembelian (http://ridwaniskandar.files.wordpress.co m) diakses 19 April 2013. 